"This is an Accepted Manuscript of an article published by Taylor \& Francis in Publications of the English Goethe Society on 19th October 2016, available online: http://www.tandfonline.com/doi/full/10.1080/09593683.2016.1224493." 


\title{
Friedrich Max Müller: The Career and Intellectual Trajectory of a German Philologist in Victorian Britain
}

\author{
JOHN R. DAVIS AND ANGUS NiCHOLLS \\ Kingston University, London, UK \\ Queen Mary University of London, UK
}

The Oxford-based German comparative philologist, Friedrich Max Müller (1823-1900), ignored for much of the time since his death, has attracted renewed scholarly interest in the last few decades of the twentieth century. This article summarises some of the existing research on Müller, while also reintroducing him as the most influential comparative philologist in Victorian Britain. Subjects examined include Müller’s early life and education, his focus on Sanskrit studies, his career in Oxford, his role as the first President of the English Goethe Society, his debates with Darwin and others on the origin and nature of language, and his broader influence on anthropological and religious questions in Victorian intellectual life.

KEYWORDS Friedrich Max Müller, comparative philology, German-British cultural relations, Carl Christian Josias von Bunsen, the English Goethe Society, Thomas Carlyle, comparative mythology, Edward Burnett Tylor, origin of language, Charles Darwin, William Dwight Whitney

\section{Introduction: rediscovering Max Müller}

For most of the twentieth century, Friedrich Max Müller was largely unknown to or ignored by historians and academics, whether in his adopted homeland Britain, in Germany where he was born and educated, or in India, the subject of much of his research. To some extent, research had moved on. Max Müller's achievements were viewed with increasing criticism and even disdain. ${ }^{1}$ He simply no longer fitted in with prevailing interests. The intellectual complexities of the nineteenth century generally attracted less interest among younger generations. The central themes of Max Müller's work - ancient Sanskrit texts and their significance to the development of myth, religion and language - lost their relevance in Europe. The First and Second World Wars put paid to sustained interest in non-military

\footnotetext{
${ }^{1}$ On which point see: The Essential Max Müller: On Language, Mythology, and Religion, ed. by Jon R. Stone (Basingstoke: Palgrave, 2002), pp. 3-4.
} 
aspects of the Anglo-German relationship. The history of Empire moved from diplomatic to peripheral explanations, and left the cultural aspects of the subject to one side.

But in the last decades of the century, interest in Max Müller began to return. A residual appreciation of the value of his work remained in the various areas in which he had published. ${ }^{2}$ However, there was also now a rising interest in the culture and identity of India, and an emerging academic consideration of Max Müller’s importance not just as a translator of Sanskrit texts but also - and more controversially - as a cultural intermediary between Europe and the Subcontinent. ${ }^{3}$ Starting in the 1960s, interest in the Victorian period also grew more generally, including in areas that made consideration of Max Müller unavoidable. The increasing focus on the literature and intellectual world of the Victorians could not help but lead to his name, given his prominence as a public intellectual and his copious correspondence with leading thinkers and figures of the day. Max Müller, based at Oxford University for most of his life and on personal terms with monarchs, prime ministers, diplomats and civil servants, was in the thick of that intense network that formed the backbone of the Victorian establishment so clearly identified by Noel Annan. ${ }^{4}$

Though the Anglo-German relationship in the nineteenth century had been reduced to a narrative of inevitable conflict, revived interest in Victorian intellectual life helped uncover the strong and sustained influence of German culture in nineteenth-century Britain. The Victorian interest in German culture encompassed philosophy, literature, classics, philology, natural sciences, history, religious thought, art, music, education, politics and economics, though the list is not exhaustive. ${ }^{5}$ In many - if not all - of these areas, Max Müller played a

\footnotetext{
${ }^{2}$ Stone, The Essential Max Müller, p. 5.

${ }^{3}$ See for example: Hermann Berger, 'F. Max Mueller: what can he teach us?' in: F. Max Mueller: What he can teach us (Bombay: Shakuntala, 1974), pp. 16-20; Nirad C. Chaudhuri, Scholar Extraordinary. The Life of Professor the Rt. Hon. Friedrich Max Müller, P.C. (London: Chatto \& Windus, 1974); Joan Leopold, 'British applications of the Aryan theory of race to India, 1850-1870', in: The English Historical Review, 89 (1974), pp. 278-603; G.W. Trompf, Friedrich Max Müller: As a Theorist of Comparative Religions (Bombay: Shakuntala, 1978); Johannes H. Voigt, Friedrich Max Müller: The Man and His Ideas (Calcutta: Mukhopadhyay, 1967).

${ }^{4}$ Noel (Lord) Annan, The Disintegration of an Old Culture (Oxford: Clarendon, 1966). Oxford, indeed, was according to Annan at the centre of 'High Culture'. He asks (p. 5) 'What better place is there to discuss culture than in Oxford?'

${ }^{5}$ Rosemary Ashton, The German Idea. Four English Writers and the Reception of German Thought, 1800-1860 (Cambridge: Cambridge University Press, 1980); John R. Davis, The Victorians and Germany (Frankfurt/Main: Peter Lang, 2007). An interesting insight into the interconnected nature of the British interest in German culture is also provided in: Susanne Stark, “Behind Inverted Commas.” Translation and Anglo-German Cultural Relations in the Nineteenth Century (Clevedon: Multilingual Matters, 1999). An earlier, German-language study which also pointed to Max Müller's intellectual connections was Klaus Dockhorn, Der Deutsche Historismus in England. Ein Beitrag zur englischen Geistesgeschichte des 19. Jahrhunderts (Göttingen: Vandenhoeck \& Ruprecht, 1950), particularly p. 164.
} 
part. In most, he was a significant player. The interest of Victorians in a variety of aspects of German culture was one factor contributing to large-scale immigration to Britain from German-speaking Europe in the nineteenth century. German expertise was sought and employed in music, art, science and education. Max Müller's place in this story, as both an example of immigration and a facilitator of it, has attracted attention. ${ }^{6}$ So too has his role in the history of British imperialism. As discussion has turned towards cultural aspects of colonialism, the function of German Indology within British imperialism has come under scrutiny. ${ }^{7}$ Meanwhile, there has been greater focus on the extent to which European writers such as Max Müller helped lay the foundations for an emerging Indian national identity and the possible implications of this for society there. ${ }^{8}$

As historical interest in the period has developed and become more specialised, researchers have investigated Max Müller from a variety of angles. Often, however, their findings have remained within their disciplinary areas and an evaluation of his role has remained compartmentalised. A complete, holistic assessment of Max Müller's significance has remained outstanding. An early attempt at a comprehensive biography of Max Müller, published by Nirad Chaudhuri in 1974, was a valiant and largely sympathetic treatment, pointing to the enormity of the subject as well as to its problematic nature, particularly with respect to India. ${ }^{9}$ Its usefulness was undermined significantly, however, by its failure to reference correctly, and it predated, and thus failed to benefit from, the new resurgence of interest in Victorian culture. More detailed and academically useful was Lourens P. van den Bosch’s Friedrich Max Müller: A Life Devoted to the Humanities, published in $2002 .{ }^{10}$ This volume revealed more clearly Max Müller's position in the history of ideas and the significance of his thought into the twentieth century. Yet a great deal of research has been published or has begun since this work was written. It is the aim of this volume to reassess once more the life and work of Max Müller, bringing together up-to-date contributions from

\footnotetext{
${ }^{6}$ Migration and Transfer from Germany to Britain, c1660-1914, ed. by John R. Davis, Stefan Manz, and Margrit Schulte-Beerbühl (Munich: Saur, 2007); Aneignung und Abwehr. Interkultureller Transfer zwischen Deutschland und Grossbritannien im 19. Jahrhundert, ed. by Rudolf Muhs, Johannes Paulmann and Willibald Steinmetz (Bodenheim: Philo, 1998), pp. 211-12.

${ }^{7}$ Transnational Networks: German Migrants in the British Empire, 1670-1914, ed. by John R. Davis, Stefan Manz and Margrit Schulte-Beerbühl (Leiden: Brill, 2012); Suzanne L. Marchand, German Orientalism in the Age of Empire: Religion, Race, and Scholarship (Cambridge: Cambridge University Press, 2009).

${ }^{8}$ Nicholas B. Dirks, Castes of Mind: Colonialism and the Making of Modern India (Princeton, NJ: Princeton University Press, 2001), p. 142.

${ }^{9}$ Chaudhuri, Scholar Extraordinary.

${ }^{10}$ Lourens P. van den Bosch, Friedrich Max Müller: A Life Devoted to the Humanities (Leiden: Brill, 2002).
} 
leading scholars in relevant disciplines and also extending its evaluation to subjects not treated before.

\section{Max Müller's emergence as a researcher}

In order to begin to understand why Max Müller rose to prominence in the nineteenth century, it is important to recognise the importance of his early years. He was born on 6 December 1828 in Dessau, in the Duchy of Anhalt-Dessau, one of the 38 German states formed after the Napoleonic Wars and organised into a loose Germanic Confederation. Essentially a citystate, Dessau was in a region where the cultures of neighbouring Saxony and Prussia, the cities of Leipzig, Dresden and Berlin, and Thuringian courts such as Saxe-Weimar were in easy reach. It was also a place where aristocrats, officials and the town population were familiar to each other. As Max Müller would later describe it, 'Everybody seemed to know everybody and everything about everybody'. ${ }^{11}$ Max Müller was born into the cultured, educated class that attended court and served as intermediaries between town and state. From an early age he was familiar with aristocrats, politicians and leading cultural figures of the times.

Max Müller’s father, Wilhelm Müller (1794-1827), came from modest circumstances, but had fought in the Napoleonic Wars, studied history and philology in Berlin, and afterwards began publishing highly popular poetry capturing the German national and Romantic spirit of the time. His poetry collections Die schöne Müllerin (1823) and Winterreise (1827) were set to music by Schubert to great acclaim. His Griechenlieder (1821-4), meanwhile, caught the popular nationalism of the early restoration years and sympathy with the Greek cause in part also fuelled by widespread interest in classics, without setting him outside what was acceptable politics at court. In 1819, Wilhelm Müller became a teacher at the Grammar School in Dessau. The year after, he took on the role of court librarian. Max Müller's mother Adelheide (1799?-1883), meanwhile, was from the Basedow family, which had occupied high ministerial positions. Both her father Ludwig von Basedow (1774-1835) and brother Friedrich (1797?-1864) were Prime Ministers of the Duchy. Her grandfather, the famous educational reformer Johann Bernhard Basedow (1724-1790) had been a friend of Goethe. All in all, Friedrich Max Müller was born into propitious circumstances. His family and courtly contacts would contribute to his cultural interests, personal and professional connections and reputation.

\footnotetext{
${ }^{11}$ Friedrich Max Müller, My Autobiography: A Fragment (London and Bombay: Longmans, Green \& Co., 1901), p. 92.
} 
This childhood world was given a severe jolt when Wilhelm Müller died in 1827 and Max Müller recalled these early years as melancholy. His education, mainly focusing on classics and religion, was conducted at first at the town public school in Dessau until Max Müller was sent, aged 12, to the Nicolai Grammar School in Leipzig. Here he lodged with Professor Carl Gustav Carus (1789-1869), whose son, Victor (1823-1903) went to school with Max Müller and who would later himself also take up a position at Oxford University. The Nicolai school was one of the most prominent and revered institutions of the day. Its list of alumni famously included Gottfried Wilhelm Leibniz (1646-1716) and its focus was almost entirely on Greek and Latin. Max Müller's passion at the time was for music. In Leipzig he renewed contact with the composer Felix Mendelssohn (1809-1847), whom he had come to know during the latter's previous appointment at the Dessau court and who was now conductor at the Gewandhaus. But he excelled at school in classics and it was his classical education that to some extent determined Max Müller’s future course.

In 1841 Max Müller entered Leipzig University with a scholarship from AnhaltDessau to study for the doctorate in philology, mainly in Greek and Latin, taught respectively by Johann Gottfried Hermann (1772-1848) and Moritz Haupt (1808-1874). However, despite learning much from them, Max Müller later described these studies as 'chewing of the cud' (My Autobiography, p. 129), and academic freedom at the university enabled Max Müller to extend his studies to other areas including philosophy and Oriental languages. Max Müller’s time at Leipzig coincided with the intellectual furore caused by G.W.F. Hegel's (1770-1831) theories of intellectual evolution which, in turn, drew him towards philosophy as an area of inquiry. At the same time, however, he encountered the ideas of Johann Friedrich Herbart (1776-1841) in the lectures of Moritz Wilhelm Drobisch (1802-1896), which he described as 'a most useful antidote' to the complexities Hegel's thought had unearthed (My Autobiography, p. 142). Herbart's ideas, combined with Max Müller's preoccupation with classical languages and philosophy, resulted in a growing fascination with what he would later identify as the 'Science of Language'. As Müller explained:

If Herbart declared philosophy to consist in a thorough examination (Bearbeitung) of concepts, or conceptual knowledge, my answer was, Only let it be historical, nay, in the beginning etymological; I was not so foolish as to imagine that a word as used at present, meant what it said etymologically. Deus no longer meant brilliant, but it should be the object of the true historian of language to prove how Deus, having meant originally brilliant, came to mean what it means now. (My Autobiography, p. 145) 
While at Leipzig, Max Müller published a new edition of his father's Griechenlieder (1844), reflecting his personal interest in his father's work and also establishing his cultural and literary lineage in the public's mind. He also, however, published a translation of the Hitopadesha - a collection of Sanskrit fables concerning statecraft - the same year. ${ }^{12}$ Müller's interest in tracing the roots of language extended his research not just to philosophy but also to languages and cultures predating Greek and Latin: Arabic, Persian and Sanskrit. It was the latter, in particular, that increasingly attracted his attention. Thus, during his time at Leipzig, he read Friedrich Schlegel's Über die Sprache und Weisheit der Indier (On the Language and Wisdom of the Indians, 1808) and K.J.H. Windischmann's Die Philosophie im Fortgange der Weltgeschichte (Philosophy in the Process of World History, 1827-1834). Together, these works left on him 'that feeling which the digger who prospects for minerals is said to have, that there must be gold beneath the surface, if people would only dig' ( $M y$ Autobiography, p. 146).

By focusing on Sanskrit and ancient Indian culture, Max Müller was moving himself into an intellectual space that was seen by many, particularly in the German states, as at the cutting edge of philosophy, philology and religious thought. Ancient Sanskrit texts, some believed, offered insight into a system of thought and belief predating the classical period, and would therefore increase knowledge of the present day by unearthing detail further in the past and by enabling greater understanding of the true, original meaning of philosophy and its concepts. Similarly, those who believed the Bible could be better understood by historical investigation than by literal interpretation believed Sanskrit texts may help cast light on the original meanings of Scripture. Despite some scepticism from an academic establishment grounded in classics, Indian texts, made accessible in the eighteenth century as a consequence of British imperial presence in the Subcontinent, were therefore increasingly read and analysed with excitement in German scholarly circles. Max Müller's demonstrable ability to translate and interpret Sanskrit texts meant he gained a network of supporters of his work.

At Leipzig, Müller was encouraged in his Sanskrit researches by J.G. Hermann, despite the latter's emphasis on Greek. He also sought out the expertise of Hermann Brockhaus (1806-1877), an eminent Sanskrit expert. ${ }^{13}$ Brockhaus had been a student of

\footnotetext{
${ }^{12}$ Friedrich Max Müller, Hitopadesa: Eine alte indische Fabelsammlung (Leipzig: Brockhaus, 1844). Later revised and republished in English as Max Müller, The First Book of the Hitopedesa (London: Longmans, Green \& Co., 1864).

${ }^{13}$ Ernst Windisch, Geschichte der Sanskrit Philologie und indischen Altertumskunde, part 2 (Berlin and Leipzig: de Gruyter, 1920), pp. 209-15.
} 
August Wilhelm Schlegel (1767-1845), one of the founders of romanticism and an eminent linguist who had spent time in both France and Britain, and was connected with most of the leading contemporary Indologists. As Müller's research progressed, however, he felt the need to spend six months in Berlin: the main purposes of this were to attend classes given by the foremost Sanskrit scholar of the day, Franz Bopp (1791-1867), to seek guidance from Friedrich Schelling (1775-1854) whose Naturphilosophie and idealism coincided with an interest in Orientalism and mythology, and to inspect the new Sanskrit texts acquired by the Prussian King and deposited in the University Library from the collection of Robert Chambers (1737-1803) recently auctioned in London. ${ }^{14}$ Whilst Max Müller was in Berlin he also made contact with Alexander von Humboldt (1769-1859) after an introduction by the Duchess of Anhalt-Dessau and took classes with Friedrich Rückert (1788-1866), the poet and Orientalist who combined Romantic verse with Indian culture and was a contemporary and fellow-traveller of Müller’s father. Through Rückert, Max Müller expanded his knowledge of Persian and Arabic. ${ }^{15}$ Via a combination of social networking and enthusiasm for Sanskrit, therefore, Max Müller rubbed shoulders with some of the leading intellectuals of the early nineteenth century.

By 1844, however, Max Müller's studies at Leipzig were complete, and his scholarship from Anhalt-Dessau therefore came to an end. The financial and professional questions facing him resulted first in a move to Paris. Here, he attempted to support himself by translating Sanskrit texts for the Indologist circle that had based itself there. During his time in Paris he expanded his connections among scholars, many of whom he met through one of his main employers Baron Ferdinand d'Eckstein (1790-1861), himself an enthusiast for Sanskrit study and an acquaintance of Friedrich Schlegel. His main concern, however, was to study with Eugène Burnouf (1801-1852), a leading linguist and, latterly, Sanskrit scholar at the Collège de France. Burnouf had begun to focus his, and his seminar's, attention on the Rg Veda, and was working on a translation of the first book. It was at this point that Max Müller came to recognise the Rg Veda's potential in philosophical and philological terms. Yet to capture this - to understand it as well as translate it - would involve removal to London: the texts necessary to his task lay in the library of the British East India Company.

Max Müller travelled to Britain for the first time in June 1846, almost a year after arriving in Paris. Once again, there was an element of inevitability about his relocation: as

\footnotetext{
${ }^{14}$ For details on this see Rosane and Ludo Rocher, The Making of Western Indology. Henry Thomas Colebrooke and the East India Company (London: Routledge, 2012), p. 143.

${ }^{15}$ Chaudhuri, Scholar Extraordinary, p. 41.
} 
the acquisition of the Chambers papers in Berlin had demonstrated, the British East India Company's presence on the Subcontinent had made Britain a primary route via which materials and knowledge relating to India entered Europe. British scholars such as William Jones (1746-1794) and Henry Thomas Colebrooke (1765-1837) had produced groundbreaking studies of Sanskrit texts, and their work had led to the founding of Asiatic Societies in India, London and Paris. In these locations, their findings had been absorbed by continental scholars, particularly from the German states, given the philosophical and philological sense of urgency there. Max Müller was warmly welcomed into the East India Company Library by its director, Horace Hayman Wilson (1786-1860). Wilson was himself an established and published expert on Sanskrit texts, had been made Boden Professor of Sanskrit at Oxford University in 1832, and had known Colebrooke.

A second, highly significant person Max Müller met in London was Baron Carl Christian Josias von Bunsen (1791-1860), the Prussian Ambassador. Again, there was a certain degree of inevitability about this encounter. As a youth and at University, Bunsen had absorbed Romantic philosophy and immersed himself in linguistic, philosophical and philological studies. He had travelled widely, and knew both Friedrich Schlegel and Schelling. Through his studies he had also come into contact with Barthold Georg Niebuhr (1776-1831), the historian of Rome, and when Niebuhr was made Prussian envoy to the Papal Court in 1815 Bunsen accompanied him as his secretary. Here he pursued wide-ranging studies of Roman as well as Egyptian history and also became close personal friends with the significant cultural figures that belonged to the German and British communities there. He also married an Englishwoman, Francis Waddington (1791-1876). After Frederick William IV came to the Prussian throne in 1840, Bunsen was sent to London as Prussian Ambassador. His English wife and affiliations, as well as his close bond with the King based on an interest in classical history and culture, made him an attractive choice. Like many contemporaries, Bunsen supported historical interpretation of Biblical scripture. The theological liberalism to which this gave rise provided a foundation for the Anglo-German Bishopric project in 1846, through which an Anglican-Prussian episcopal see was to be founded in Jerusalem. Bunsen's theological position, combining deep spirituality with Hegelianism, as well as his association with Niebuhr - whose work on Rome was causing a deep stir in classical circles in Britain also brought him close to the emerging Broad Church movement in England based around the Germanophile Anglican priest Augustus Hare (1795-1855), and also to Oxford and Cambridge Universities. This movement, believing that religion might only survive if it 
accommodated scientific study, found itself increasingly opposed by established methods of learning and in favour of educational reform.

Bunsen was clear that German scholarship, particularly as it related to history, philology and religion, could bring benefits to Britain. He was also convinced - in typically Hegelian fashion - that world history would be well served by ever-closer cooperation between Britain and Prussia. Bunsen had met Max Müller's father during his time with Niebuhr in Rome. ${ }^{16}$ Interestingly, Bunsen had also already taken an interest in Max Müller’s fate in 1844, when he had attempted to secure a tutor's post for the young scholar after being contacted by Alexander von Humboldt. After Max Müller's later arrival in London, Bunsen took an active and enthusiastic role in supporting his progress. Müller's area of scholarship was one he had long been interested in, and he was particularly keen to unravel the meaning of the Rg Veda and weave it into his own theories regarding the evolution of religion. Here was a scholar whose findings might serve to demonstrate the value of German research in a variety of areas and, in particular, contribute directly to historical approaches to theology. Bunsen used his considerable prestige in the British establishment in the 1840s to sway the East India Company towards supporting publication of the Rg Veda and, in so doing, provided Max Müller with financial security for the intermediate future. He also showcased Müller by inviting him regularly to the Prussian Embassy to meet leading figures of the day and by ensuring his participation in a presentation to the British Association for the Advancement of Science at Oxford in 1847. Bunsen informed Müller that 'We must show them what we have done in Germany for the history and philosophy of language, and I reckon on your help'. ${ }^{17}$

\section{Oxford: Max Müller's professorial career}

Max Müller's move to Oxford the next year seems a natural step, given that the printing of the Rg Veda was taking place there and he had to consult manuscripts in the Bodleian Library. In fact, with revolutions affecting the German states in 1848, his correspondence suggests serious consideration of a return to his homeland. ${ }^{18}$ Later that year, however, he was offered the post of temporary lecturer in modern European languages at the Taylor Institution, to

\footnotetext{
${ }^{16}$ Friedrich Max Müller, 'Wilhelm Müller’, Allgemeine Deutsche Biographie, https://de.wikisource.org/wiki/ADB:M\%C3\%BCller,_Wilhelm_(Dichter), accessed 28 July 2016.

${ }^{17}$ Chaudhuri, Scholar Extraordinary, p. 61.

${ }^{18}$ See, for example, his letters to Bunsen dated 18 May and 13 June 1848, Max Müller Papers, MS. German d.22, Bodleian Libraries, University of Oxford. See also Chaudhuri, Scholar Extraordinary, pp. 105-6.
} 
replace another Orientalist and an acquaintance of Max Müller's, Friedrich Heinrich Trithen (1820-1854). ${ }^{19}$ The post did not provide security at first and it was also significant that this was not a Fellowship in a college but a lecturing post in an adjunct body to the University. A Fellowship required adherence to the Anglican faith and was restricted to ordained priests.

From his arrival, there was sustained suspicion of Max Müller at Oxford due to a notion that he sympathised with the Broad Church movement. Such suspicions would have been exacerbated by the fact that many of those he developed friendships with at Oxford some of whom he had gotten to know via Bunsen - belonged to the Broad Church position. Their number included Matthew Arnold (1822-1888), James Anthony Froude (1818-1894), Benjamin Jowett (1817-1893), F.D. Maurice (1805-1872), Robert Morier (1826-1893), and A.P. Stanley (1815-1881). Sarah Barnette's contribution to this volume also reveals that George Eliot (Mary Anne Evans, 1819-1880) - the translator of David Friedrich Strauss and Ludwig Feuerbach - was an avid reader of Müller, even incorporating some of his ideas into novels such as Middlemarch (1871-2) and Daniel Deronda (1876). Max Müller's connections with liberal circles became even closer by marriage: his wife, whom he met in 1853, was the niece of the wives of Froude and Charles Kingsley (1819-1875), another prominent religious liberal. As the Broad Church fought against the established structures of higher education at Oxford and Cambridge in the 1850s, religious differences became entangled with university politics and Max Müller's position within all this continued to provide a serious challenge to his professional career.

After a Liberal government was elected in 1846, its Prime Minister, Lord John Russell, had set in train a process of Higher Education reform, creating a Royal Commission to investigate Oxford University's collegiate and tutorial systems in $1852 .{ }^{20}$ The reforms proposed, which included allowing the appointment of non-Anglican Fellows, a modernisation of the curriculum, and the introduction of Professorial and research-based teaching, met stiff resistance, particularly from High Church interests. They viewed such changes as opening the way to speculative, German-style education that, in turn, might

\footnotetext{
${ }^{19}$ On Trithen, see Windisch, Sanskrit-Philologie, p. 380.

20 'Report of Her Majesty's Commissioners...into...the university and colleges of Oxford: together with the evidence, and an appendix', Parliamentary Papers, 12 (1852).
} 
threaten religious orthodoxy. Max Müller's research area, social contacts and German origins meant he was quickly identified by conservatives as part of the reformist camp. ${ }^{21}$

The post at the Taylor Institution provided a foothold in Oxford. From here, Max Müller was able to continue translating and publishing the Rg Veda - the first volume of which appeared in 1849 - and thus also to raise his profile. For classical scholars - and their number included most of the establishment both in education as well as in politics and the Church - his research represented a significant addition to knowledge, whether or not they wished to hear it. His sociability, famous lineage, important connections, and musical abilities all helped gain him support among academics and facilitated what today might be termed networking. And his research, particularly due to its religious significance, gained him enemies but also admirers. His temporary lectureship was converted into an assistant professorship in 1850 and, by 1854, he had secured Trithen’s Chair itself. In 1857 he was made an honorary Fellow at All Souls College - the first unmarried Fellow at the College.

Yet the barriers to Max Müller's professional development arising from his theological and educational leanings would be illustrated clearly when in 1860 he sought, but failed, to secure the Boden Chair in Sanskrit at Oxford, earlier occupied by Wilson. The Chair was instead awarded to Monier Monier-Williams (1819-1899), who was regarded by the High Church opponents of educational and religious reform as a far safer candidate. In 1867, despite failing to secure the Boden Chair, he was appointed Chair of Comparative Philology at the Taylor Institution. While this appointment recognised Max Müller’s status and his achievement in having established a new discipline, it was nevertheless a professorial appointment outside the collegiate university structure. It also failed to recognise his particular achievements in relation to Sanskrit.

\section{INSERT IMAGE 1}

Plate 1: 'Sensational Fours Entering the Gut': Max Müller (foreground) as cox in charge of a crew of reformers, notably trailing against the crew of Monier Monier-Williams at Oxford. ${ }^{22}$

\footnotetext{
21 For more on this see: John R. Davis, 'Higher Education Reform and the German Model: A Victorian Discourse', in: Anglo-German Scholarly Networks, ed. by Heather Ellis and Ulrike Kirchberger (Leiden: Brill, 2014), pp. 39-62.

${ }^{22}$ From 1224 Caricatures of Oxford University Life, 7 vols. (Oxford: Thomas Shrimpton and Son, 1868-92), I, item 61; G.A. Oxon $4^{\circ} 412$ (v.1), Item 61, The Bodleian Libraries, University of Oxford. Monier-Williams’s crew members are (left to right): Robert Bullock Marsham (cox), Warden of Merton College; Monier MonierWilliams, Boden Professor of Sanskrit; Richard Michell, Anglican cleric, Vice Principal and later Principal of Hertford College; Drummond Percy Chase, Principal of St. Mary Hall, a conservative in educational matters; and Edward Hawkins, Provost of Oriel College and an opponent of the Oxford Movement and of educational
} 
No matter how eminent or well-known he became, therefore, Oxford continued to resist giving Max Müller unfettered access to its hallowed cloisters. His frustrations regarding this contributed to him considering a move elsewhere or a return to German academe. Ties to his homeland were a factor, and German unification in 1871 led to a renewed engagement with German politics that extended to attempting to influence views in Britain. Nevertheless, his chances of progression or recognition at Oxford were often the occasion of thoughts of relocation. In 1875, probably in reaction to Monier-Williams being awarded an honorary doctorate for his contribution to Sanskrit studies, Max Müller announced his proposal to resign from the post of Chair of Comparative Philology. ${ }^{23}$

\section{INSERT IMAGE 2}

Plate 2: Max Müller threatens to resign. ${ }^{24}$

The prospect caused immediate uproar in Oxford. Reflecting the public profile that Max Müller had by this time gained, it also caused a stir in the national newspapers, with the Telegraph and the Globe all carrying long articles in defence of his work and contribution. ${ }^{25}$ Ultimately, however, the balance always remained in favour of his remaining in Oxford.

To some degree, therefore, one can interpret Max Müller's rise and trajectory as an academic in a deterministic fashion, noting the circumstances of his birth and his lineage, the nature and priorities of German scholarship in the early nineteenth century, the AngloGerman cultural relationship, and the era of reform in mid-Victorian Britain. Yet other aspects should also be considered that have more to do with factors of personality. Just as Bunsen had clearly identified the value in bringing the achievements of German researchers to Britain, Max Müller appeared to take on the mantle of intermediary between the two cultural realms. Using his growing status as an Oxford-based academic, he actively promoted the immigration and employment of German philologers and academics in Britain. He began

reform. Max Müller’s crew are: Max Müller (cox); John Phillips, Deputy Reader in Geology; James Edwin Thorold Rogers, Drummond Professor of Political Economy, involved in radical politics and later a branch founder of the Reform League in Oxford; The Reverend James Norris, President of Corpus Christi College; John Matthew Wilson of Corpus Christi, an early proponent of reform in Oxford.

23 Chaudhuri, Scholar Extraordinary, p. 230.

${ }^{24}$ From 1224 Caricatures of Oxford Life, II, item 302; G.A. Oxon $4^{\circ} 413$ (v.2), Item 302, The Bodleian Libraries, University of Oxford.

258 December, The Globe; 8 December 1875, Daily Telegraph. Interestingly, Max Müller entered into correspondence with Vienna University regarding a Chair. The correspondence relating to this is at: MS.Eng.c.2808, Max Müller Papers, the Bodleian Libraries, University of Oxford. 
translating and producing edited collections of German literature which he felt needed to be brought to the attention of British readers, either for the contribution they might make to better British understanding of German thought (for example, Kant) or because he felt the riches of German culture had not been adequately displayed (for example, Goethe). Max Müller and his wife also took on the task of translating and editing the memoirs of Baron Stockmar (1787-1863). ${ }^{26}$ In so doing, they clearly demonstrated a desire to bring their translation skills, expertise and position to bear on a figure that was central to Baron Bunsen's Hegelian aspirations for the Anglo-German alliance. Stockmar had been the closest confidant of Prince Albert and Queen Victoria.

Max Müller also took the decision to progress beyond engagement with academics and to become a prominent public intellectual. He moved from the translation and analysis of texts and myths to show their wider significance in other disciplines - such as comparative mythology, the history of language, and comparative philology. He began to explain his findings to a non-academic audience, particularly through his lectures. Meanwhile, as British interest in India rose after the Indian rebellion in 1857, Max Müller became an important conduit for and authority on Indian culture in Britain.

\section{INSERT IMAGE 3}

Plate 3: Max Müller (centre) as an 'Eastern Sage’, pictured with Archibald Henry Sayce (left, 1845-1933), Professor of Assyriology at Oxford, a student and later friend of Müller; and Professor James Legge (right, 1815-1897), Professor of Sinology at Oxford and a collaborator with Müller on the Sacred Books of the East project. $^{27}$

He increasingly took part in important public discussions on a wide variety of subjects. In particular, Müller played an active role in relation to German politics, Darwinian theories of evolution, and Britain’s administration of India. Max Müller's work on India and his commitment to better understanding between Britain and Germany would make him a welcome guest at Queen Victoria’s dinner table. He supported his public work via private discussions with colleagues, politicians, civil servants, scholars, royalty and religious interests both at home as well as abroad. Through his many publications, lectures and letters on all

\footnotetext{
${ }^{26}$ Memoirs of Baron Stockmar, 2 vols., trans. by Georgina Adelaide Max Müller, ed. by Friedrich Max Müller (London: Longmans, Green \& Co., 1872).

${ }^{27}$ From 1224 Caricatures of Oxford Life, V, item 902; G.A. Oxon $4^{\circ} 416$ (v.5), Item 902, The Bodleian Libraries, University of Oxford.
} 
these subjects, Max Müller became one of the most well-known academics of the Victorian period, working the media in a way unknown at the time though far more familiar today. Despite obstacles faced at Oxford University, therefore, Max Müller enjoyed an influence that was national and international.

\section{Max Müller and the English Goethe Society}

An indicator of Max Müller's success and prominence as a cultural mediator between Germany and Victorian Britain can be identified in his having been asked to serve as the first President of the English Goethe Society (EGS), and this special issue of the Society's Publications marks Müller's role in the inauguration of the EGS. The EGS was founded in 1886 in order to 'promote and extend the study of Goethe's work and thought, and to encourage original research upon all subjects connected with Goethe'. ${ }^{28}$ It is the third-oldest Goethe Society in the world, having come into existence after the Wiener Goethe-Verein (1878), the Goethe Gesellschaft in Weimar (1885), and other smaller Goethe societies in Germany. From the beginning, contact between the London Society and its sibling in Weimar was close: the London publisher Alfred Trübner Nutt appears to have instigated the formation of the EGS, and in order to do so he wrote to one of the founders of the Weimar Goethe Gesellschaft, Freiherr August von Loën. ${ }^{29}$ Members of the EGS who paid the full membership fee of 'one guinea per annum' were automatically registered with its sibling Society in Weimar, receiving its publications. ${ }^{30}$ While the EGS of today is very much a scholarly society for both academics and interested laypersons, having no explicit political or diplomatic aims, this was probably not the case at its inception. In his comparative analysis of the German Shakespeare Gesellschaft and the EGS around the period of the Great War, Peter Edgerly Firchow has shown that these literary societies were far from being apolitical, especially during times of tension and conflict, and in this respect the EGS appears, at least in its early phases, to have been no exception. ${ }^{31}$

\footnotetext{
${ }^{28}$ The English Goethe Society, First Annual Report of the Council, English Goethe Society Rules, rule II. Presented to the Business Meeting, London, 1 December 1886, Institute of Germanic and Romance Studies, EGS. 2.1.A. See also the Masters dissertation of Fabienne Schopf, Die Anfänge der English Goethe Society 1886-1914 (University of Stuttgart, 2014).

${ }^{29}$ H. G. Fiedler, Memories of Fifty Years of the English Goethe Society - An Address delivered by Professor H.G. Fiedler at the Conversazione held at University College London on 25 February 1936 (Cambridge 1936), p. 3.

${ }^{30}$ First Annual Report to the Council, English Goethe Society Rules, rule III.

${ }^{31}$ Peter Edgerly Firchow, 'Shakespeare, Goethe and the War of the Professors, 1914-1918,' in: Strange Meetings: Anglo-German Literary Encounters from 1910-1960 (Washington D.C.: Catholic University of America Press, 2008), pp. 56-97.
} 
Some of the prominent early members of the EGS were indeed academics, not politicians or diplomats, with an interest in German literature and thought: John Stuart Blackie (1809-95), the translator of Faust ${ }^{32}$ who had studied in Germany with Ottfried Müller, August Boeckh and Friedrich Schleiermacher and who made his name as a classical scholar at Aberdeen University; Oscar Browning (1837-1923), the historian at King's College Cambridge and author of Goethe: His Life and Writings (1892); Karl Breul (1860-1932) - a former student of the prominent neo-Kantian Friedrich Paulsen and of the positivist Goethe specialist Wilhelm Scherer - who was appointed as Lecturer in German at Cambridge and who later became the first Schröder Professor of German Language and Literature there; ${ }^{33}$ John Robert Seeley, the Regius Chair of Modern History at Cambridge and the author of The Life and Times of Stein, or, Germany and Prussia in the Napoleonic Age (3 vols., 1878); and Adolphus Ward (1837-1924), Professor of History and of English Language and Literature at Owens College, Manchester (later to become the University of Manchester), who translated Ernst Curtius's Griechische Geschichte into the five-volume study The History of Greece (1868-73), who would later deliver the Ford Lectures at Oxford which were published as Great Britain and Hanover (1899), and who finally wrote the major historical work Germany 1815-1890, published in three volumes between 1916 and 1918.

But alongside these academic Germanists and Germanophiles, the early membership of the EGS also included prominent figures from the worlds of royalty, diplomacy and parliamentary politics. These included Prince Christian of Schleswig-Holstein (1831-1917) and his wife Princess Helena (1846-1923), the fifth child of Queen Victoria and Prince Albert; James Russell Lowell (1819-1891), the American poet, critic, Harvard Professor and at that time US Ambassador to the Court of St James's; and George Joachim Goschen (First Viscount Goschen, 1831-1907), a Director of the Bank of England, elected member of parliament, and finally Chancellor of the Exchequer from 1887 until 1892. It was no doubt this mixed membership - combining academia, royalty and the highest echelons of politics that saw in Max Müller a likely first President. Müller’s academic credibility, alongside his high-level connections to British royalty and to both British and German diplomats and politicians, would have made him an attractive choice for a Society with both cultural and at least latently political aims. Certainly there were better-qualified Goethe specialists within

\footnotetext{
${ }^{32}$ J. W. Goethe, Faust: A Tragedy, translated in English verse by John Stuart Blackie (Edinburgh: William Blackwood, 1834).

33 See Sylvia Jaworska, 'Anglo-German Academic Encounters before the First World War and the Work towards
Peace: The Case of Karl Breul', Angermion, 3 (2010), 135-60.
} 
the membership than Müller, including both Browning and Blackie, but they could not rival his political connections or his social cache.

On the academic side, Müller did admittedly hold a distinguished position in modern languages at Oxford, and he had edited the major anthology The German Classics from the Fourth to the Nineteenth Century (1858), ${ }^{34}$ the second volume of which included an extensive section on Goethe. Nonetheless, this hardly qualified Müller as a Goethe specialist, and as this special issue of the Society's Publications demonstrates, his academic reputation was far stronger in the fields of comparative philology, Sanskrit and comparative religion than it was in the field of German literature. In short: like the Shakespeare Gesellschaft in Germany, the EGS seems initially to have been conceived not only to explore Goethe's writings and their cultural contexts, but also to promote relations between Britain and Germany during a time of political tension between a well established colonial power and a recently unified nation with its own emerging naval and colonial aspirations. Viewed in this broader political context, the choice of Max Müller makes sense.

When Friedrich Althaus of London, the author of Englische Charakterbilder (English Character Portraits, 1869), ${ }^{35}$ wrote to Müller in early 1886, requesting that he become first President of the EGS, Müller responded precisely by underlining the diplomatic dimensions of a post that he declared himself reluctant to take on:

If I lived in London, nothing would have given me greater pleasure than to act as President of the English Goethe Society. That Society ought to exercise a very powerful influence on English thought, and draw the two nations, the English and the German, very close together through their common sympathy with Goethe. As in philosophy we say 'Back to Kant!' we shall have to say 'Back to Goethe!' in poetry and in all that can help us once more to believe in those high ideals of life which guided him from his youth to his old age. An English Goethe Society, if properly supported, might do much good to both England and Germany. It would show to the Germans that England has still a warm heart for all that is truly noble; and it would show to the English that Germany can still appreciate those to whom she owes her real and lasting greatness. With two such ambassadors as Shakespeare and Goethe, we should soon have a true alliance between Germany and England, an alliance

\footnotetext{
${ }^{34}$ The German Classics from the Fourth to the Nineteenth Century, ed. and trans. by Friedrich Max Müller (London: Longman, Brown, Green, Longmans and Roberts, 1858).

${ }^{35}$ Friedrich Althaus, Englische Charakterbilder (Berlin: R. v. Decker, 1869).
} 
independent of changing cabinets, and firmly founded on mutual respect and love. But the same reasons which have obliged me to decline all honorary fellowships elsewhere, would make it impossible for me to accept the Presidency of the English Goethe Society [...] You want an active President, a man who moves in society, and is on the spot whenever he is wanted. Try to get a man like Lord Acton, Lord Arthur Russell, Mr. Goschen, Mr. Froude - would that Carlyle were still among the living! My lot is cast here - I am growing old, and even a journey to London has become an effort. ${ }^{36}$

Eight days later, in another letter to Althaus dated March 12, Müller provisionally agreed to take on the Presidency, requesting that his duties be limited to no more than two visits to London per year (Life and Letters, II, pp. 195-96).

\section{Müller's inaugural lecture to the English Goethe Society: Goethe and Carlyle}

Müller delivered the inaugural lecture of the Society, subsequently published as a stand-alone volume in the first edition of the Society's Publications, ${ }^{37}$ on 28 May 1886. The lecture's subject - 'Goethe and Carlyle' - grew out of mediating work that Müller had recently done for his friend Froude (mentioned in the letter above by Müller as a possible EGS President). As one of Carlyle's most prominent disciples, Froude had been bequeathed his papers and was therefore charged with writing his biography, which appeared in four volumes between 1882 and $1884 .^{38}$ In his lecture, Müller mentions having written to his contacts in Weimar in order to secure on behalf of Froude copies of Goethe's letters to Carlyle that could no longer be found among Carlyle's papers. Erich Schmidt, who was appointed Director of the Goethe Archive in Weimar in 1885, replied by saying that copies of most of Goethe's letters were available, and Müller reports that permission to have them copied for Froude was then granted by the Grand Duchess of Saxe-Weimar (Goethe and Carlyle, pp. 11-12). He also refers to a planned complete edition of the Goethe-Carlyle correspondence to be published in

\footnotetext{
${ }^{36}$ Max Müller to Dr. Althaus, Oxford, 4 March 1886, in: The Life and Letters of the Right Honourable Friedrich Max Müller, ed. Georgina Müller, 2 vols. (London: Longmans, Green and Co., 1902), II, p. 196.

${ }^{37}$ Friedrich Max Müller, Goethe and Carlyle, An Inaugural Address Delivered to the Society by the President, Professor F. Max Müller, 28 May 1886, Publications of the English Goethe Society, 1 (1886).

${ }^{38}$ James Anthony Froude, Thomas Carlyle: A History of the First Forty Years of His Life, 1795-1835, 2 vols., (London: Longmans, Green and Co., 1882); Thomas Carlyle: A History of His Life in London, 1834-1881, 2 vols. (London: Longmans, Green and Co., 1884).
} 
English, edited by Charles Eliot Norton, which later appeared in $1887 .^{39}$

Goethe's correspondence with Carlyle took place between 1824 and 1831, and it is particularly the final stages of this correspondence (from 1827 onwards) that are of interest to Müller in his inaugural lecture. In these late letters, Goethe was responding to Carlyle's Life of Schiller, which had appeared in 1825, and for which Goethe would later write a foreword to accompany the German translation. ${ }^{40}$ As the emotional tones of that foreword suggest (see FA, I, 22, pp. 870-1), Goethe was moved by the image of a young Scotsman engaging with the works of his departed friend. This personal encounter with international literary reception seems to have inspired Goethe to write to Carlyle at some length on the subject of world literature - one of Goethe's most successful designations, and one very much in vogue today $^{41}$ - and it is world literature that forms the basis of Müller's highly political lecture.

The political context sketched by Müller at the beginning of his lecture is one in which 'international relations between the leading countries of Europe have become worse than among savages in Africa' (p. 3). Müller does not refer to any specific political events, but one need only recall the Berlin conference of November 1884 - during which Africa was divided up between the European colonial powers, now including Bismarck's Germany - to realise that Germany's emergence as an imperial power was a cause of significant diplomatic tension in Britain. This backdrop of colonial expansion is then contrasted with the Germany of 'Lessing, Wieland, Herder, Schiller, and Goethe', which Müller describes as having been idyllic: 'the valley in which those poets lived was narrow, their houses small, their diet simple, but their hearts were large, their minds soared high, their sympathies embraced the whole world'. Immersing oneself in this world is, in Müller's words,

like taking a header into the sea at the end of a sultry day - it is a washing, a refreshing, a complete rejuvenescence all in one [...] To pass an hour with Goethe now and then will reinvigorate our belief in the much-derided ideals of life, it will make us remember our common humanity. (p. 4)

In this connection, Müller recommends Goethe's 'cosmopolitan sympathies, and, more particularly, his constant endeavours after what he called eine Welt-literatur, a World-

\footnotetext{
${ }^{39}$ Charles Eliot Norton, ed., Correspondence between Goethe and Carlyle, (London: Macmillan, 1887).

${ }^{40}$ Goethe, ‘Vorwort zu Carlyles Leben Schillers’, FA, I, 22, p. 872.

${ }^{41}$ See, for example, David Damrosch, 'Introduction: Goethe Coins a Phrase,' in: What is World Literature? (Princeton, NJ: Princeton University Press, 2003), pp. 1-36.
} 
literature' as being a kind of remedy for the political ills of contemporary Europe (p. 5, emphasis in the original). This also allows Müller to situate the idea of world literature within a larger historical scope that is better suited to his normal academic mode: that of the speculative comparative philologist who ranges freely across the history of humanity.

This 'ideal of a universal republic of letters' is, in Müller's view 'a dream that has been dreamt long before Goethe' (p. 6), arguing that only in the last four centuries of European history had there been a parochial retreat into national literatures. Here the 'Egyptian monuments' and the 'palaces of Babylon and Niveveh' are presented as having been the 'rudiments of a world-literature' (p. 6), and these early beginnings were later succeeded by Latin as the literary language of the Middle Ages (p. 9). What distinguishes Goethe's idea of world literature is not its claims to universality, but rather the idea of 'intellectual free-trade' according to which 'each country should produce what it could produce best, and the ports of every country would welcome intellectual merchandise from whatever part of the world it might be sent' (pp. 9-10).

Here Carlyle’s correspondence with Goethe becomes relevant for Müller. Goethe, he argues, not only saw his exchanges with Carlyle as a form of international literary commerce involving the best minds of Europe; he also viewed them as a means of progressing towards better international relations. In Müller's translation of Goethe's letter to Carlyle of 20 July 1827, literary exchange is not seen as heralding 'the approach of an era of universal peace', but it may at least see 'strifes which are unavoidable grow less extreme, wars less savage, and victory less overbearing' (pp. 15-16). Most important of all for Müller's political argument is Goethe's idea that 'we arrive best at true toleration when we can let pass individual peculiarities [...] holding fast, nevertheless, to the conviction that genuine excellence is distinguished by this mark, that it belongs to all mankind' (p. 16, emphasis in the original).

By now it should be clear that Müller had in mind, if not an explicitly political EGS, then at least a Society that could exercise what diplomats refer to as 'soft power'. Although Müller conceded that 'we do not wish that our Society should ever become a political society', he nevertheless expressed the hope that 'we may soon count some of the leading statesmen of England’ among its members (p. 23). In Müller’s view

literature, too, has its legitimate influence, at first on individuals only, but in the end on whole nations [...] Goethe's spirit has become not only a German power, not only a European power, it has become a force that can move the whole world. That force is now committed to our hands, to use it as best we can. (p. 24) 
From the tone of this final passage in particular, one can see that Müller's lecture was very much a public performance, presented with rhetorical skill and pathos. Indeed, at times the lecture’s sentiment appears rather heavily to outweigh its actual argument.

Goethe’s Weimar, presented by Müller as a quaint and bucolic haven, was arguably far more exposed to the turbulences of European politics than was Britain of the late nineteenth century. And Goethe himself was a political actor of some importance, contradicting Müller's image of him as a simple poet of nature at sympathy with the world. To a significant extent, the cause of the contemporary tension between Britain and Germany referred to by Müller lay outside of Europe, outside of 'history' as Hegel had defined it, ${ }^{42}$ and even beyond the 'world' of world literature as Müller and even at times Goethe understood it (here one recalls Goethe’s telling formulation, 'europäische, d.h., Weltliteratur', WA, I, 42/2, p. 500). ${ }^{43}$ It was those so-called 'savages in Africa' mentioned at the beginning of Müller's lecture who suffered most from the political forces to which he alludes but fails to confront or examine in his lecture. Müller's problematic ideas about colonial politics are discussed elsewhere in this volume, most notably in the chapter by Baijayanti Roy.

As a political statement on the aims of the EGS, Müller's lecture expresses normative political intentions to which few Europeans could have objected in 1886. And today, after the United Kingdom's referendum decision to leave European Union, Müller’s emphasis on European cosmopolitanism might even be seen to provide a renewed sense of purpose to the EGS in difficult times: that of tending to, and if necessary repairing, the many and complex cultural bridges between the United Kingdom and German-speaking Europe. Yet as the recent case of Brexit has underlined, it is not only the broad political sentiments that matter, but also the actual political mechanisms through which they should be realised. Here Müller is admittedly rather vague on how his cosmopolitan values should be actualised in concrete political terms. As Pascale Rabault-Feuerhahn's and Bernhard Maier's contributions to this volume show, the charge that Müller's lectures were often full of lofty sentiments but lacking in rigour was not infrequently made as his fame developed. Nonetheless, his inaugural lecture is likely to have hit the right notes for an audience made up of academics, politicians, diplomats and laypersons.

\footnotetext{
42 '[Afrika] ist kein geschichtlicher Weltteil, er hat keine Bewegung und Entwicklung aufzuweisen' (Africa is no historical part of the world, it has no movement and no development to exhibit). G.W.F. Hegel, Vorlesungen über die Philosophie der Geschichte, in: Werke, vol. 12, ed. Eva Moldenhauer and Karl Markus Michel (Frankfurt am Main: Suhrkamp, 1986), p. 129.

${ }^{43}$ European, that is, world literature.
} 


\section{Max Müller's impact upon British thought - the role of philology}

Müller's correspondence concerning his Presidency of the EGS and his subsequent ruminations on the subject of world literature allude to two of the main areas in which he contributed to British intellectual life. Just as world literature has become central to contemporary discipline of comparative literature, so too is Müller's interest in this subject likely to have been inspired by his own contributions to the comparative method - which emerged from his initial discipline of philology and went on to influence the origins of both anthropology and religious studies in the Anglophone world. And when, in his letter to Althaus, Müller compares the promotion of Goethe to the clarion-call of neo-Kantianism back to Kant! - he invokes the philosopher who was the key weapon in his battle against British materialism. Müller's translation of Kant's first Critique - the Kritik der reinen Vernunft (Critique of Pure Reason, 1781-87), a volume that Müller described as his 'constant companion through life ${ }^{44}$ - appeared in 1881. In his battle with Darwin on the philosophy of language, undertaken in the early 1870s, Müller claimed that Kant's rebuttal of Hume's empiricist materialism was a decisive victory that was still yet to be fully appreciated in the English-speaking world, nearly one hundred years after it had been won. ${ }^{45}$ Further to this, Müller's apparently 'Kantian' insistence on the identity between language and thought would also play into his understanding of religion as an attempt to conceptualise the infinite. In some ways, then, at least in Müller's conceptions of them, the 'comparative method' and Kant's critical philosophy went hand in hand and formed two pillars of Müller's academic identity in the second of the half of the nineteenth century. The British reception of these two pillars was mixed: while Müller's contributions to the comparative method saw him become a leading figure in comparative philology and comparative religious studies - even exerting an influence upon the first British anthropologists - it was his later recourse to Kantian arguments in his debates with Darwin that contributed to the decline in his reputation.

An assessment of Max Müller's importance for nineteenth-century British thought must first of all recognise the importance of philology during that century. In his recent study Philology: The Forgotten Origins of the Modern Humanities (2014), James Turner has proposed that philology - by which he means at once textual philology (encompassing

\footnotetext{
${ }^{44}$ Immanuel Kant, Immanuel Kant's Critique of Pure Reason: In Commemoration of the Centenary of its First Publication, trans. by F. Max Müller, (London: Macmillan, 1881), p. xiii.

${ }^{45}$ Friedrich Max Müller, 'Lectures on Mr. Darwin’s Philosophy of Language', Fraser's Magazine, 7-8 (1873), 526-41, 659-78, 1-24 (529).
} 
classical and biblical studies, as well as 'Oriental' languages such as Sanskrit and Arabic); theories of the origin of language; and finally the comparative study of the development of languages - was the 'king of the sciences' during the nineteenth century. ${ }^{46}$ Turner argues that Müller was a key figure within all three of those subsections of philology: his six-volume edition of the Rg Veda (1849-74) and his fifty-volume edition of the Sacred Books of the East (1879-1910) made him for a time the preeminent scholar of 'Oriental' religions in Britain (pp. 236-39); his two volumes of Lectures on the Science of Language $(1861,1864)$ and his later exchanges with Darwin on the origin of language saw him placed at the centre of debates about the place of human beings within the theory of evolution (pp. 244-47); and as Robert A. Segal's contribution to this volume demonstrates, Müller's work on comparative mythology and comparative religion was foundational for the new discipline of religious studies, with his Introduction to the Science of Religion (1873) offering, in Turner's words, 'the first learned methodology for comparative study of religion' (p. 373). This theoretical approach to the study of religion was then supplemented by the vast collection of the Sacred Books of the East, which, as Arie L. Molendijk shows in this volume, laid the foundations for the textual study of comparative religion.

Why, then, did Max Müller's reputation as a scholar decline as the century drew to a close? The story of Müller's career can usefully be contextualised within the larger account offered by Turner concerning the fate of philology in the second half of the nineteenth century. To cut this long story short: the textual discipline which promised to do nothing less than explain the origin of language and the relations of different languages to one another, to clarify the origin and function of myth and the cognitive dimensions of religion, and to explain the relationship between so-called 'primitive' and 'advanced' cultures, eventually lost in a battle of prestige with the natural sciences. As Turner observes:

Until the natural sciences usurped its throne in the last third of the nineteenth century, philology supplied probably the most influential model of learning. The immense resonance of philology as a paradigm of knowledge is much less well known today than the parallel influence of natural science, because science won and philology lost. Victors often erase the footprints of the defeated. (pp. x-xi)

\footnotetext{
${ }^{46}$ James Turner, Philology: The Forgotten Origins of the Modern Humanities (Princeton NJ: Princeton University Press, 2014), p. x.
} 
Here an important factor in the fate of philology was the shift in the definition of 'science' that took place around the middle of the nineteenth century - a shift of which Müller was highly aware and which he attempted to accommodate from the 1860s onwards.

William Whewell, the English philosopher who coined the term 'scientist' in 1833, argued in 1840 that 'science' refers not only to knowledge concerning the material world, but also to any systematic area of study, including philology. ${ }^{47}$ This more general definition of 'science' is retained today in the German Wissenschaft, which is still used in relation to humanities disciplines such as literary studies (Literaturwissenschaft). But in mid nineteenthcentury Britain, 'science' came increasingly to mean 'physical' or 'natural' science: a mode of inquiry based on hypotheses about the physical world tested via an experimental method, as is evidenced in the following quotation from the Dublin Review of 1867: 'we shall [...] use the word "science" in the sense which Englishmen so commonly give to it; as expressing physical and experimental science, to the exclusion of the theological and metaphysical' ${ }^{48}$ As we shall see, the fact that Müller's arguments about the origin of language ended up being idealist, and in that sense 'metaphysical', led to the decline of his reputation in linguistics, but did not necessarily detract from his status in the field of comparative religion. Here Turner's conclusion about Müller's long-term impact is also instructive: 'Max Müller’s genuinely humanistic vision of "the science of language" [...] did not lead to an enriched philology. It led instead out of the discipline of linguistics into a new discipline of comparative religion' (p. 251).

Max Müller's most decisive early intervention into British academic life was the publication of his 1856 'essay’ - really a book-length treatise - on Comparative Mythology. The method used in this essay was derived from the already existing work on comparative philology - in particular the similarities between Ancient Greek and Sanskrit - initially uncovered by Sir William Jones in his 'Third Anniversary Discourse' of 1786 and later expanded upon in Friedrich Schlegel's Über die Sprache und Weisheit der Indier and in Franz Bopp’s Vergleichende Grammatik (Comparative Grammar, 1833). The hypothesis posited by all of these thinkers was that concerning a primordial 'Aryan' language that predated ancient Greek and Sanskrit. By looking at similarities between ancient Greek and Sanskrit language roots and the myths that allegedly arose from them, Müller argued that comparative philology

\footnotetext{
${ }^{47}$ William Whewell, The Philosophy of the Inductive Sciences, Founded Upon Their History, $2^{\text {nd }}$ ed., 2 vols., (London: J.W. Parker, 1847 [1840]), I, p. 3. See also: Richard Yeo, Defining Science: William Whewell, Natural Knowledge and Public Debate in Early Victorian Britain (Cambridge: Cambridge University Press, 1993), p. 10.

${ }^{48}$ W.G. Ward, 'Science, Prayer, Free Will, and Miracles’, Dublin Review, April (1867), 255-98 (255).
} 
could function as a 'telescope of great power', providing insight into a period 'when Sanskrit was not yet Sanskrit, Greek not yet Greek, but when both, together with Latin, German and other Aryan dialects, existed yet as one undivided language'. ${ }^{49}$ We note here the scientific metaphor of the telescope, and Müller's claim that comparative philology would allow 'the archives of the most distant antiquity of the Aryan race' finally to be opened (p. 26).

Yet the story that Müller told in Comparative Mythology about the development of humanity did not necessarily suit the second half of the nineteenth century, since it was not one of unalloyed scientific progress. The ancient 'Aryans', he argues, used abstract gendered substantives in order to refer to natural forces such as the earth, the sea, the sun, the sky and the seasons. One such example is the Hindu God Dyaus, associated with the sky and sun, and known as the god who lights the sky. Dyaus according to Müller's etymology, is derived from root div or dyu, meaning to 'shine' or 'brighten', which is in turn said to underlie the IndoEuropean derivations of deva, deus and deity. Because these abstract substantives were always gendered in ancient Greek and Sanskrit, it was 'simply impossible to speak of morning or evening, of spring and winter, without giving to these conceptions something of an individual, active, sexual and at last personal character' (pp. 72-3). Myth therefore emerges from 'that particular difficulty which the human mind experiences in speaking of collective or abstract ideas' (p. 78). What originally began as simple metaphorical descriptions of natural phenomena later proliferated into fully blown myths and creation stories which assigned human personalities to natural forces, an allegedly degenerative process that would later lead Müller famously and pejoratively to describe myth as a 'disease of language'. ${ }^{50}$ In his contribution to this volume, Andreas Musolff investigates this notion of the disease of language' at length, exploring both its historical and contemporary relevance to theories of metaphor and myth.

Müller's project was an Enlightenment one insofar as he suggested that the 'science of mythology' could diagnose this 'disease', but he nonetheless maintained that there had been a kind of falling off from the clear and primordial linguistic designations of the ancient 'Aryans'. This story of decay was also repeated in Müller's deeply controversial view of contemporary Hinduism, which he saw as a 'rotten tree' that had degenerated from the pure (and in his view monotheistic) conception of the divine expressed in the Vedas, into the polytheistic pantheon (for further context, see the contributions to this volume by Thomas J.

\footnotetext{
${ }^{49}$ Friedrich Max Müller, Comparative Mythology: An Essay (1856), ed. by A. Smythe Palmer (London: Routledge, 1909), pp. 21-22.

${ }^{50}$ Friedrich Max Müller, Lectures on the Science of Language, Delivered at the Royal Institution of Great Britain in April, May \& June 1861, $3^{\text {rd }}$ ed. (London: Longman, Green, Longman, and Roberts, 1862), pp. 11-12.
} 
Green and Baijayanti Roy). ${ }^{51}$ Although recognised during his lifetime as an expert on India, and despite the fact that all Goethe Institutes in India still carry the name of Max Mueller Bhavan in his honour, ${ }^{52}$ Müller appears to have had a limited understanding of contemporary India, and indeed no real desire to go there. ${ }^{53}$ Müller's preferred image of India remained that of the ancient land of the Vedas.

More controversial still, especially from the present day perspective, is Müller’s contribution to and popularisation of the 'Aryan' discourse, a subject which has generated an extensive secondary literature. ${ }^{54}$ Thomas R. Trautmann has shown that Müller’s interpretation of a passage from the Rg Veda (5.29.10), published in 1854 in a volume edited by Bunsen, led to links being made between the 'Aryan' identity and physical characteristics associated with 'race'. Here Müller suggests that the north Indian 'Aryans' had longer noses that the 'flat-nosed' people of southern of India. ${ }^{55}$ Although, in Trautmann's opinion, Müller made this questionable interpretation only tentatively and quite early on in his career, it stuck. ${ }^{56}$ But this should not necessarily lead to the conclusion that Müller's Aryanism was in any way proto-Nazi. Conceived in the context of British imperialism in India, Müller also deployed the idea of 'Aryan brethren' in order to underline what he thought to be an ancient kinship between the Hindus in India and their British colonisers, a suggestion which met with great controversy among British ethnologists who were keen to emphasise the separateness and superiority of the British (see Trautmann, Aryans and British India, pp. 178-81). This notion

\footnotetext{
${ }^{51}$ Friedrich Max Müller to Baron von Bunsen, Oxford, 25 August 1856, in Life and Letters, I, pp.190-94 (p. 191).

${ }^{52}$ In India, Müller’s name tends to be written without an Umlaut.

${ }^{53}$ When Müller was asked by Arthur Stanley (Dean of Westminster) to accompany the then Prince of Wales (Edward Albert) on a royal visit to India in 1875, he replied by stating: 'My curiosity to see India is not very great. It is the inner life, not the outward show I care for; and I can see more of the former from reading books'. Müller to Dean Stanley, Oxford, 12 August 1875, in: Life and Letters, I, pp. 519-20.

${ }^{54}$ See Leon Poliakov, The Aryan Myth: A History of Racist and Nationalist Ideas in Europe, trans. by Edmund Howard (London: Heinemann, 1974), see in particular pp. 213-14; Tony Ballantyne, Orientalism and Race: Aryanism in the British Empire (Houndsmills, Basingstoke: Palgrave, 2002), pp. 41-44; Thomas R. Trautmann, Aryans and British India (New Delhi: Yoda Press, 2004), pp. 172-78; Thomas R. Trautmann, (ed.), The Aryan Debate (New Delhi: Oxford University Press, 2005), especially chapter 7, pp. 84-105; Stefan Arvidsson, Aryan Idols: Indo-European Mythology as Ideology and Science, trans. by Sonia Wichmann (Chicago: University of Chicago Press, 2006), pp. 46-9.
}

\footnotetext{
${ }^{55}$ See Friedrich Max Müller, 'The Last Results of the Researches Respecting the non-Iranian and non-Semitic Languages of Asia or Europe, or the Turanian Family of Language', in: Outlines of the Philosophy of Universal History Applied to Language and Religion, ed. Christian Charles Josias Bunsen, 2 vols. (London: Longman, Brown, Green and Longmans, 1854), I, pp. 263-521 (p. 346).

${ }^{56}$ Thomas R. Trautmann, 'Constructing the Racial Theory of Indian Civilization', in: The Aryan Debate, pp. 84105 (p. 101).
} 
of 'brethren' was nonetheless perfectly compatible with British imperialism, since as Stefan Arvidsson argues, it suggested that the 'Aryan' peoples consisted of two halves: the 'expanding, experimenting and conquering' Europeans, and the 'introverted and insightful' Indians (pp. 47-8). And despite Müller's later disclaimer to the effect that linguistic categories are not to be equated with ethnological or racial classifications, ${ }^{57}$ his many statements concerning the so-called 'Aryan' nations - including one that describes them as the 'rulers of history ${ }^{58}$ - provided ample fuel for later thinkers who had more nefarious purposes in mind. Again, Baijayanti Roy's contribution to this volume has much to say on this subject.

The very fact that Müller's ideas could become so controversial demonstrates the power of philology to captivate the public mind around the middle to later stages of the nineteenth century. As George Stocking has argued in Victorian Anthropology (1987), Müller's version of comparative philology amounted to a kind of 'linguistic palaeontology', suggesting that philology could offer an account of the prehistory of humankind. It was this historical element that endowed comparative philology with both 'a reconstructive as well as a genealogical interest' for early British anthropologists. ${ }^{59}$ The sticking point, however, was the problem of development: while Müller's work on comparative mythology proposed what was in part a degenerative model, the mainstream of British evolutionary thought - predating Darwin - thought of human history almost exclusively in terms of progress. In this connection, the key thinker was Herbert Spencer, who in his essay 'Progress its Law and Cause' (1857) argues that both in biology and in human civilizations one can observe processes of development that lead from simplicity into complexity: 'The series of changes gone through during the development of a seed into a tree, or an ovum into an animal', according to Spencer, 'constitute an advance from homogeneity of structure to heterogeneity of structure'. Spencer proposed to show that 'that this law of organic progress is the law of all progress', including progress in human societies. ${ }^{60}$

This emphasis on progress was in turn taken up by Edward Burnett Tylor who, like Müller, was an academic at Oxford, and who became the first Professor of Anthropology in

\footnotetext{
57 'There are Aryan and Semitic languages, but it is against all rules of logic to speak [...] of an Aryan race, of Aryan blood, of Aryan skulls, and to attempt ethnological classification on purely linguistic grounds'. Friedrich Max Müller, 'On the Results of the Science of Language, Inaugural Lecture Delivered at the Imperial University of Strassburg, May 23, 1872', in: Chips from a German Workshop, 4 vols. (New York: Scribner, 1881), IV, pp. 199-226 (p. 211).

58 Friedrich Max Müller, A History of Ancient Sanskrit Literature (London: Williams and Norgate, 1859), p. 15

${ }^{59}$ George Stocking, Victorian Anthropology, (New York: The Free Press, 1987), pp. 56-62.

${ }^{60}$ Herbert Spencer, 'Progress its Law and Cause’, Westminster Review, 67 (1857), 445-85 (446).
} 
Britain in 1896. In Primitive Culture (2 vols.,1871), Tylor proposes a three-stage model of civilizational development, according to which the most 'primitive' or animistic stage of civilization is succeeded first by the 'monotheistic' and finally the 'scientific' stages. Contemporary so-called 'savages' (such as the Aborigines of Australia) are described by Tylor 'animistic' and are thought by him to provide an insight into the prehistory of more 'advanced' (i.e., North European) civilizations. ${ }^{61}$ In the mid 1860s, Tylor followed Müller's work closely and was impressed by the anthropological prospects for comparative philology. Of particular attraction was the proposition of a basic likeness across separate cultures and language groups, which suggested universal laws of human development. And within the strict of field of linguistic development, Müller's contention that languages develop from basic roots into more complex and inflected modes of expression seemed to confirm Spencer's and Tylor's notion that progress involves a movement from simplicity to complexity (Lectures on the Science of Language, pp. 267-69). After the publication of Darwin's Origin of Species in 1859, Müller also added a Darwinian element to this picture by claiming that just as the 'struggle for life' takes place between biological organisms, so too is there a process of 'natural elimination' of 'the less strong, the less happy, the less fertile' words within languages that Müller explicitly associates with 'natural selection' (Lectures on the Science of Language, p. 390, emphasis in the original).

In a lengthy review of Müller's Lectures on the Science of Language published in 1866, Tylor applauds what he regards as Müller's 'consistent and scientific theory of the development of language from a few simple root-words upwards to the most expressive' ${ }^{62} \mathrm{At}$ the same time, however, he expresses a word of caution concerning Müller's theory not of the development, but of the origin of language. Müller proposes that the most primitive and basic language roots or 'phonetic types' were originally produced by 'a power inherent in human nature' that corresponds with the 'rational conceptions' of the human mind (Lectures on the Science of Language, pp. 391-92, emphasis in the original). Here Tylor correctly identifies the influence of Kant's notion of a priori categories on Müller, describing Kant as ‘a philosopher brilliant and subtle indeed, but, to our thinking, ages behind himself in scientific method' (pp. 423-24). In the same review, Tylor goes on to defend two of the theorists of language who were criticised by Müller in his Lectures on the Science of Language, and upon whom Darwin

\footnotetext{
${ }^{61}$ See Angus Nicholls, 'Anglo-German Mythologics: The Australian Aborigines and Modern Theories of Myth in the Work of Baldwin Spencer and Carl Strehlow', History of the Human Sciences 20, no. 1 (2007), 83-114.

${ }^{62}$ Edward Burnett Tylor, review of Müller's Lectures on the Science of Language, Hensleigh Wedgwood's A Dictionary of English Etymology, and Frederic W. Farrar's Chapters on Language, The Quarterly Review, 119 (January and April 1866), 394-435 (423).
} 
would later draw upon in the Descent of Man: Hensleigh Wedgwood and Frederic Farrar. As Michela Piattelli's paper in this volume shows, Wedgwood's Dictionary of English Etymology (3 vols., 1859-65) offers an imitative account of the origin of language, according to which the earliest words arose from the imitation of external phenomena such as animals. ${ }^{63}$ Similarly, Farrar, in his Chapters on Language (1865), argues that the earliest words arose from imitations and emotional interjections. ${ }^{64}$ In his assessment of these theorists of language, Tylor identifies 'a certain amount of scientific value' in the works of Wedgwood and Farrar, a value to which he thinks 'Professor Müller seems scarcely to do justice' (p. 425). Here Tylor was already close to the position on language that Darwin would later endorse in the Descent of Man.

\section{Müller's debate with Darwin on language and its broader cultural significance}

Müller's Kantian theory of the origin of language is elaborated at greater length in his three 'Lectures on Mr Darwin’s Philosophy of Language', delivered in May-July 1873. The debate between Müller and Darwin has been explored at length in the secondary literature, ${ }^{65}$ and since it is also revisited in two papers in this volume (those by Michela Piattelli, and by Marjorie Lorch and Paula Hellal) only a brief account is required here. The key distinction is that made by Müller, in his second lecture on Darwin, between emotional and rational language. Müller attributes emotional language to imitations and interjections; rational language, by contrast, arises from a priori concepts in the human mind akin to Kant's categories. Whereas imitative and interjectional language can, in Müller's view, be found among both humans and higher animals, only humans have the capacity for rational language and more generally for abstract concepts, which form 'the frontier [...] between man and beast' ('Lectures on Mr Darwin's Philosophy of Language', p. 678). For Müller, the copresence of abstract concepts and articulate language forms two sides of the same coin, and

\footnotetext{
${ }^{63}$ Hensleigh Wedgwood, A Dictionary of English Etymology, 3 vols. (London: Trübner, 1859-65).

${ }^{64}$ Frederic Farrar, Chapters on Language (London: Longmans, Green and Co., 1865).

${ }^{65}$ See Linda Dowling, 'Victorian Oxford and the Science of Language', PMLA, 97 (1982), 160-178; Gregory

Schrempp, 'The Re-Education of Friedrich Max Müller: Intellectual Appropriation and Epistemological Antinomy in Mid-Victorian Evolutionary Thought', Man, 18 (1983), 90-110; Elizabeth Knoll, (1986) 'The Science of Language and the Evolution of Mind: Max Müller's Quarrel with Darwinism', Journal of the History of the Behavioural Sciences, 22 (1986), 3-22; Robert J. Richards, Darwin and the Emergence of Evolutionary Theories of Mind and Behavior (Chicago: Chicago, University of Chicago Press, 1987), pp. 200-206; Lourens P. van den Bosch, 'Language as the Barrier between Brute and Man: Friedrich Max Müller and the Darwinian Debate on Language', Saeculum, 15 (2000), 57-89; Angus Nicholls, 'A Germanic Reception in England: Friedrich Max Müller’s Critique of Darwin’s Descent of Man’, in: The Literary and Cultural Reception of Charles Darwin in Europe, ed. by Thomas F. Glick and Elinor Shaffer (London: Bloomsbury, 2014), pp. 68-90.
} 
these faculties are, in his view, exclusively to be found in humans. For him there could be no developmental continuum between inarticulate (that is, imitative and interjectional) language on the one hand and the articulate language of human beings on the other. By deploying this Kantian argument, Müller sought to land a decisive blow not only against Darwin's philosophy of language, but also ultimately against his entire theory of human descent.

Müller sent these lectures to Darwin, evidently hoping for a public debate with the new giant of British 'physical' science, and remarking that the 'interjectional and mimetic theories of the origin of language are no doubt very attractive and plausible, but if they were more than that, one at least of the great authorities in the science of language - Humboldt, Bopp, Grimm, Burnouf, Curtius, Schleicher, \& c. - would have adopted them' (Life and Letters, I, p. 477). Darwin decided not to engage in direct combat with Müller, diplomatically replying that he felt himself unworthy of debating with him on matters relating to language, but claiming that 'he who is convinced, as I am, that man is descended from some lower animal, is almost forced to believe a priori that articulate language has been developed from inarticulate cries’ (quoted in Müller, Life and Letters, I, p. 478).

Yet this private rebuttal was evidently not enough for the Darwin camp, and what followed was a sustained campaign against Müller, waged by Darwin's son George, who invoked the authority of the American Sanskrit specialist William Dwight Whitney (18271894). ${ }^{66}$ Whitney had long been an opponent of Müller (for further context, see Pascale Rabault-Feuerhahn's contribution to this volume), and argued, contra Müller's Kantian rebuttal of Darwin, that it was perfectly possible for animals to have something akin to abstract conceptions of things - for example, of other animals, or of space and time - without having articulate language. In this way, Whitney refused to rule out the idea that 'an increase of the intelligence possessed by some of the lower animals' could potentially 'lead up to the vastly superior intelligence of man himself'. ${ }^{67}$ George Darwin’s article of November 1874 adopted and extended this position of Whitney, describing it as a 'powerful attack' upon Max Müller’s arguments against his father. ${ }^{68}$ The cries of animals, George Darwin proposes - and here he goes beyond Whitney's more tentative formulation - can establish themselves as

\footnotetext{
${ }^{66}$ For a comprehensive account of Whitney's role in this debate, including his alliance with Darwin against Müller, see Stephen G. Alter, William Dwight Whitney and the Science of Language (Baltimore, MD: Johns Hopkins University Press, 2005), pp. 174-206.

${ }^{67}$ William Dwight Whitney, 'Darwinism and Language', The North American Review, 119, no. 244 (1874), 6188 (71-74, quote from p. 83).

${ }^{68}$ See George H. Darwin, 'Professor Whitney on the Origin of Language', Contemporary Review (November, 1874), 894-904 (894).
} 
conventions and therefore become rudimentary articulate languages, a position that underlines a developmental continuum between animal and human mentality (p. 902). This argument is then reiterated by Charles Darwin in the second edition of the Descent of Man, in which he directly replies to Müller's lecture series of 1873, proposing that animals like dogs do have general conceptions of things to which they can relate certain words. ${ }^{69}$ Müller in turn responded to the Darwins (and to Whitney) in a paper published in 1875, in which he dismisses the idea that animals can have conceptual knowledge, while also claiming that Whitney had unwittingly been influenced by and essentially agreed with his Lectures on the Science of Language, doing little more than paraphrase them. ${ }^{70}$

While Müller's debate with Darwin can be seen as a paradigm case of the larger battle alluded to by James Turner between philology and the natural sciences - a debate decisively won by the latter party - Müller's most vehement, persistent and successful opponent lay firmly within the field of philology itself: William Dwight Whitney. Perhaps more than any other of Müller's many opponents, Whitney - himself a graduate of German comparative philology, having studied with Bopp and with the Indologist Albrecht Weber in Berlin, and with the Indologist Rudolph von Roth in Tübingen ${ }^{71}$ - understood Müller’s difficult position in Victorian intellectual life. Whitney saw that Müller was a philologist whose worldview had been decisively formed by German intellectual currents belonging to the first half of the nineteenth century - chiefly romanticism and idealism - but who, in a series of rear-guard actions, sought to adapt his intellectual orientation to the intellectual climate of Victorian Britain, characterised as it was by the rise of Darwinism and more generally of 'physical' science. It was Whitney's professed aim to expose Müller's 'scientific' arguments about language as being little more than strategic and rhetorical.

To this end, Whitney devoted an entire volume to his critique of Müller. ${ }^{72}$ Here he focuses on two themes that are relevant to the present discussion. The first is Müller's claim that the 'Science of Language' is a 'physical science' that identifies natural laws of

\footnotetext{
${ }^{69}$ Charles Darwin, The Descent of Man, and Selection in Relation to Sex, $2^{\text {nd }}$ ed., 2 vols. (London: John Murray, 1874), I, pp. 88-9.

${ }^{70}$ Friedrich Max Müller, 'My Reply to Mr. Darwin’, in: Chips from a German Workshop, vol. 4., Essays Chiefly on the Science of Language (London: Longmans, Green and Co., 1875), pp. 433-72.

${ }^{71}$ See Turner, Philology, pp. 239-40.

${ }^{72}$ William Dwight Whitney, Max Müller and the Science of Language: A Criticism (New York: D. Appleton and Co., 1892).
} 
development that are beyond human control. ${ }^{73}$ While Whitney observes that probably no student of language who has any claim to public attention' would agree with Müller on this point (p. 23), he does find one precedent: the German comparative philologist August Schleicher (1821-1868). A close collaborator with the German Darwinian Ernst Häckel (1834-1919), Schleicher had proposed as early as 1860 that languages are 'natural organisms' that grow according to 'particular laws'. ${ }^{74}$ And after having read Heinrich Georg Bronn's translation of the Origin of Species, Schleicher then went on to claim, in an open letter to Häckel, ${ }^{75}$ that natural selection is operative in language change, a position that, as we have seen, Müller also adopted in 1861 (Lectures on the Science of Language, p. 390).

Müller and Schleicher eventually parted ways on this subject: Müller claiming language as the ultimate barrier between 'brutes' (i.e., animals) and man, and Schleicher proposing, six years before Darwin, that the operation of natural selection in language proves that human beings emerged from lower species, ${ }^{76}$ which in turn led Darwin to include Schleicher within the linguistic considerations found in the Descent of Man (I, p. 56-7). But despite Schleicher having been one of the authorities on language deployed by Darwin, Whitney described Schleicher's and Müller's claim that language is a physical or natural science as being spurious: as early as 1867, he saw the language-as-organism hypothesis as having a purely 'analogical' or metaphorical status: languages, he argues, are not empirical objects and exist only insofar as they are spoken. Far from being subject to natural laws, languages are 'human institutions' shaped solely by the communities that speak them. The laws governing languages are therefore social and human, not natural, and linguistics is exclusively a 'historical or moral science'. ${ }^{77}$ In focusing upon the role played by discourse communities in language change, Whitney anticipates Ferdinand de Saussure, who, in the historical chapter of the Cours de linguistique générale (Course in General Linguistics, 1916), cites Whitney as having provided the 'first impetus' towards the modern science of

\footnotetext{
${ }^{73}$ Müller writes in the Lectures on the Science of Language, p. 37: 'We must distinguish between historical change and natural growth. Art, science, philosophy, and religion all have a history; language, or any other production of nature, admits only of growth'.

${ }^{74}$ August Schleicher, Die Deutsche Sprache (Stuttgart: Cotta, 1860), p. 33.

${ }^{75}$ August Schleicher, Die Darwinsche Theorie und die Sprachwissenschaft. Offenes Sendschreiben an Herrn Dr. Ernst Häckel (Weimar: Böhlau, 1863).

${ }^{76}$ August Schleicher, Über die Bedeutung der Sprache für die Naturgeschichte des Menschen (Weimar: Böhlau, 1865).

${ }^{77}$ William Dwight Whitney, Language and the Study of Language: Twelve Lectures on the Principles of Linguistic Science (New York: Charles Scribner, 1867), pp. 48-9.
} 
linguistics. Müller, meanwhile, is classed by Saussure as belonging to the more antiquated school of 'comparative philology' associated with Bopp, and his final and wholly damning judgment on Müller bears the influence of Whitney: Müller, he remarks, successfully 'popularized' comparative philology in his 'brilliant discussions' on the 'Science of Language', but 'his failing was a certain lack of conscientiousness'. ${ }^{78}$

The second key theme of Whitney's attack on Müller relates to Müller's invocation of Kant in his debate with Darwin. In Whitney’s words: Müller 'thought to stop Darwinism by quoting Kant against it' (Whitney, Max Müller, p. 75). Müller's critique of Darwin relied on the argument that articulate language emerges from an a priori human faculty for forming abstract concepts found in all human beings, even the most allegedly 'primitive'. This would suggest a purely non-physical or mental origin of articulate language, as opposed to the interjectional and onomatopoeic theories of Wedgwood and Farrar, which see language in Humean terms as a reaction to external impressions. Yet Müller insisted too, probably for strategic or rhetorical reasons, that the science of language is a 'physical' science that develops according to natural laws. Responding to this contradiction in Müller's methodology, Whitney writes:

Probably those who hold this doctrine, of the identity of thought or reason with language, is as small as the number of those who hold that the study of language is a physical science. But [...] the number of those who hold the two doctrines together is [...] limited to our author [i.e., Müller] himself. It takes a mind very peculiarly constituted to contain them both without being disturbed by their repugnance. (pp. 2930)

Whitney seems to have correctly identified Müller's predicament: that of a philologist deeply influenced not only by Kant and German idealism, but also by an instinctively religious objection to the implications of Darwinism for questions of human descent. Müller's virtually impossible task was to make his Kantian-cum-religious theories of language and mythology seem plausible in the deeply empiricist age of 'physical science'.

Müller's debates with Tylor and Darwin concerning the origin of language had a broader cultural significance that extended well beyond purely philological or linguistic questions. When Müller claimed that the ancient 'Aryans' of the Vedas were capable of forming a conception of the infinite embodied in primitive language roots that referred to the

\footnotetext{
${ }^{78}$ Ferdinand de Saussure, Course in General Linguistics, ed. by Charles Bally and Albert Sechehaye, introd. and trans. by Wade Baskin (New York: Philosophical Library, 1959), pp. 3-5.
} 
sun, he saw in such expressions 'that feeling of dependence, of hope, of joy and faith in higher powers, which is the source of all wisdom, the spring of all religion' (Comparative Mythology, p. 124). Locating an allegedly monotheistic religious impulse or faculty at such an ancient stage of human development threw into question the animism-monotheism-science model of civilizational progress proposed by Tylor, and a similar triad of magic-religionscience outlined by James George Frazer in the second (1900) edition of The Golden Bough. ${ }^{79}$ It also threatened to undermine existing approaches to missionary activity in colonised territories such as the Indian Subcontinent, since Müller suggested - either scandalously or progressively, depending upon one's point of view ${ }^{80}$ - that Christian missionaries in India should seek to find the common (allegedly monotheistic) core that he thought united Christianity and Hinduism, and which might lead to a new 'reformed' religion combining both traditions (a topic explored by both Thomas J. Green and by Stéphanie Prévost and Laurent Dedryvère in their contributions to this volume). ${ }^{81}$

\section{INSERT IMAGE 4}

Plate 4: Max Müller in Later Years. ${ }^{82}$

In this way, Müller set himself against powerful elements of the British Christian establishment as well as against the dominant school of early British armchair anthropology, which held great prestige up until its displacement by the first methodologically informed fieldwork anthropologists of the early twentieth century such as Franz Boas and Bronislaw Malinowski. Accordingly, the contemporary journalist and secularist John Mackinnon Robertson (1856-1933) refers in his Christianity and Mythology (1900), to the 'etymological and solar schools’ which in Britain emerged predominantly from the ideas of Max Müller,

\footnotetext{
${ }^{79}$ See Frazer's 'Preface to the Second Edition', in: The Golden Bough: A Study in Magic and Religion, $3{ }^{\text {rd }}$ ed., 8 vols. in 12 (New York: Macmillan, 1935), I, p. xx.

${ }^{80}$ Müller's reputation among Hindus remains to this day ambivalent because of these missionary ideas. Here one can usefully compare the essentially positive account of his life offered by Nirad C. Chaudhuri in Scholar Extraordinary with the version told by Brahm Datt Bharti and entitled Max Muller (sic): A Lifelong Masquerade. The Inside Story of a Secular Christian Missionary who Masqueraded all his Lifetime from Behind the Mask of Literature and Philology and Mortgaged his Pen, Intellect and Scholarship to Wreck Hinduism (New Delhi: Erabooks, 1992).

${ }^{81}$ See Müller, ‘Westminster Lecture, On Missions’ (1873), in: Chips from a German Workshop, 4 vols.
(London: Longmans, Green and Co., 1867-1875), IV, pp. 251-290 (pp. 268-269).

${ }^{82}$ MS. Minn 196, Image 196/11, The Boldeian Libraries, University of Oxford, reproduced courtesy of Major Sir Guy Acland.
} 
and assumed a primal monotheism at the earliest phases of human history, and to an 'anthropological school' associated mainly with Tylor and Frazer, which theorised that the most primitive cultures are pre-religious and animistic or magical. ${ }^{83}$ In relation to Christianity and anthropology, then, just as in the case of the 'Science of Language', Max Müller found himself increasingly consigned to the outer edges of British intellectual life as the century drew to a close, and his 'sciences' of language and of mythology did not survive into the twentieth century as serious academic theories. At the same time, however, their dominant role in the second half of the nineteenth century was central to shaping these disciplines in their twentieth-century manifestations.

\section{The papers in this volume}

This volume is organised according to a two-fold system. The first section deals with the impact of Max Müller's philological work upon a series of contemporary intellectual debates regarding theories of language, myth, metaphor and religion. The chapters show how Max Müller's thought differed from, challenged, or contributed to these fields, thereby revealing the breadth of his impact. On the one hand this section points to the reasons for the ultimate rejection of his position by the end of the nineteenth century, not least the rise of natural and empirical sciences. Yet it also demonstrates how Max Müller’s work, even while it was discarded, helped to define and establish new disciplinary and intellectual landscapes.

To begin with Michela Piattelli shows how Max Müller's theory of language formation led to an engagement with Darwinian theories of evolution via the work of Hensleigh Wedgwood. Marjorie Lorch and Paula Hellal explore the implications of Max Müller's theory that thought and language are inseparably connected, illustrating how this theory was picked up, absorbed by, and then challenged by a range of new and emerging disciplines. In so doing, however, they also convey how interaction with Max Müller's work helped distinguish and construct these disciplines. Andreas Musolff demonstrates how Max Müller developed his argument that languages evolve through 'decay' to make a much broader contribution to discussions about cultural evolution. In so doing, he shows how Max Müller's arguments regarding metaphor and mythology led to important contributions to the fields of both philosophy and linguistics that are still relevant today. Robert Segal examines the ways in which Max Müller’s theory of mythology was developed concurrently with this theory of religion. Religion in Max Müller’s view arises out of man's experience of the 'infinite', represented by natural phenomena such as the sun, while mythology evolved

\footnotetext{
${ }^{83}$ John M. Robertson, Christianity and Mythology (London: Watts, 1900), pp. 19-51. See also George Stocking's account of Müller’s reception by British anthropologists in Victorian Anthropology, pp. 305-10.
} 
through linguistic 'disease'. According to Müller's position, religion is primary while mythology is secondary and decadent, which is precisely the opposite view to that of Tylor. Yet as Segal shows, while these theories provided a significant contribution to Victorian religious studies, they would yet again be overtaken as approaches based in anthropology and in the social sciences, rather than in religion itself, took hold. Finally, Pascale RabaultFeuerhahn investigates the way in which Max Müller's comparative philology was received, and then propagated, by others. By focusing in particular on the Italian comparative philologist Angelo de Gubernatis, she shows that the processes of transfer and also the impact of Max Müller’s approach and scholarship were by no means linear. Indeed, national or cultural differences could lead to distortions, reminding us that, even though his reach was obviously strong and evident abroad, any evaluation of Max Müller's impact is a more complex exercise than at first thought.

The second section of this volume in one sense appears to narrow its focus to consider one area in particular in which Max Müller’s work would make an important contribution: religious studies. Yet its papers reveal that in this area Max Müller made a significant and lasting contribution, though not always in ways that were intended. By comparing Max Müller's work with that of others in this area, meanwhile, the individuality of his contribution is made more evident. Arie L. Molendijk investigates Max Müller's editorial role in the compilation of the Sacred Books of the East, and, in so doing, highlights its importance as one of the first such comprehensive, sustained, monumental and modern academic projects. At the same time, however, Molendijk reveals how the project had important intellectual and cultural side-effects, leading for example to a connection of the East with religion in Western minds as well as to a textual interpretation of religions - after the model of the Bible - in the 'Orient'. Bernhard Maier offers a comparison of Max Müller’s career and work with that of his contemporaries, in particular with the Semiticist and Arabist William Wright. In so doing, he points to the importance of biographical and cultural contexts in explaining Max Müller's significance. He also, however, reveals the challenges that Max Müller and his colleagues faced and the astounding success with which he met.

Thomas Green pursues the biographical theme, exploring Max Müller's own religious standpoint in the context of his theory of religion. Green shows that Max Müller's theories regarding the value of Vedānta were also of personal significance and part of an evolving belief regarding the future course of Christianity. Sarah Barnette's chapter illustrates the influence of Max Müller's 'Science of Language' and his 'Science of Religion' outside of strictly academic circles. By focusing on the impact of his thought on George Eliot, 
Barnette's chapter demonstrates that Max Müller's religious thinking attracted the attention of literary intellectuals, and was both absorbed and echoed by them. Bringing the themes discussed by Green and Barnette together, the chapter by Laurent Dedryvère and Stéphanie Prévost explores Max Müller's position on Christianity in greater depth, focusing in particular on his notions regarding religious reform. In so doing, they recall, and encourage speculation upon, Max Müller's interaction with the English Broad Church movement. They also, however, reveal how Max Müller managed to combine a simple personal Christian belief with far-reaching and unorthodox positions. Finally, Baijayanti Roy points forward to the impact of Max Müller's religious scholarship into the twentieth and twenty-first centuries. By focusing on Müller's significant role as an intermediary between the West and Hindu culture, Roy demonstrates that he constructed historical and comparative theories in such a way as to emphasise ‘Aryan' links between Europe and India. In so doing, according to Roy, Max Müller unwittingly contributed to the construction of identities that had a lasting and in many ways negative impact in both India and Germany. Her paper is a final reminder that, though Max Müller's scholarly work had been in many respects left behind by the start of the twentieth century, its impact was not just far-reaching and lasting but also complex and problematic.

\section{Acknowledgements}

The papers in this volume were first delivered at the conference Friedrich Max Müller and the Role of Philology in Victorian Thought, German Historical Institute, London, 16-18 April 2015. The authors would like to thank the German Historical Institute, in particular Andreas Gestrich and Carole Sterckx, for supporting this conference academically, logistically and financially. We would also like to thank the Modern Humanities Research Association for a conference grant that helped to make the event possible, and the English Goethe Society for supporting the publication of the conference papers. Colin Harris of the Bodleian Library provided invaluable assistance in accessing the Max Müller papers held there, and we thank Major Sir Guy Acland for granting us permission to reproduce an image of Max Müller held in the Bodleian. Some of the material presented here appears in other contexts in the following articles: John R. Davis, 'Higher Education Reform and the German Model: A Victorian Discourse', in: Anglo-German Scholarly Networks, ed. by Heather Ellis and Ulrike Kirchberger (Leiden: Brill, 2014), pp. 39-62; Angus Nicholls, 'A Germanic Reception in England: Friedrich Max Müller's Critique of Darwin’s Descent of Man', in: The Literary and Cultural Reception of Charles Darwin in Europe, vol. 3, ed. by Thomas F. Glick and Elinor 
Shaffer (London: Bloomsbury, 2014), pp. 78-100; 'Max Müller the Comparative Method', Comparative Critical Studies, 12, no. 2 (2015), 213-34.

\section{Notes on Contributors}

John R. Davis is Professor of History and International Relations at Kingston University, London. His book publications include The Victorians and Germany (2007) and (co-edited with Stefan Manz and Margrit Schulte Beerbühl) Migration and Transfer from Germany to Britain, c1660-1914 (2007) and Transnational Networks: German Migrants in the British Empire, c.1660-1914 (2012).

Correspondence to: j.davis@kingston.ac.uk

Angus Nicholls is Reader in German and Comparative Literature at Queen Mary University of London. His book publications include Goethe's Concept of the Daemonic: After the Ancients (2006), Thinking the Unconscious: Nineteenth-Century German Thought (co-edited with Martin Liebscher, 2010), and Myth and the Human Sciences: Hans Blumenberg's Theory of Myth (2015). He co-edits the journals History of the Human Sciences and Publications of the English Goethe Society.

Correspondence to: a.j.nicholls@qmul.ac.uk 
